\title{
A REFORMA TRABALHISTA BRASILEIRA NA DINÂMI- CA DA ECONOMIA E SEUS IMPACTOS NA REGULAÇÃO PÚBLICA DO TRABALHO: EM DIÁLOGO COMPARADO COM A REFORMA EM ANDAMENTO NA ARGENTINA.
}

BRAZILIAN LABOR REFORM IN THE DYNAMICS OF ECONOMY AND ITS IMPACTS ON THE PUBLIC REGULATION OF LABOR: A COMPARED DIALOG WITH ONGOING REFORM IN ARGENTINA. LA RÉFORME DE LA MAIN-D'EUVRE BRÉSILIENNE DANS LA DYNAMIQUE DE L'ÉCONOMIE ET SES EFFETS SUR LA RÉGLEMENTATION PUBLIQUE DU TRAVAIL: EN DIALOGUE AVEC LA RÉFORME EN COURS EN ARGENTINE.

LA REFORMA LABORAL BRASILEÑA EN LA DINÁMICA DE LA ECONOMÍA Y SUS IMPACTOS EN LA REGULACIÓN PÚBLICA DEL TRABAJO: EN DIÁLOGO COMPARADO CON LA REFORMA EN MARCHA EN ARGENTINA.

\author{
Magda Barros Biavaschi* \\ Marilane Oliveira Teixeira**
}

RESUMO: $O$ artigo discute os sentidos da "reforma trabalhista" brasileira, vigente desde novembro de 2017, a partir da dinâmica da economia, em diálogo comparado com a reforma em andamento na Argentina, buscando demonstrar a falácia dos argumentos de seus defensores e, nesse cenário, abordar certos aspectos dessa reforma e seus impactos no sistema de regulação que inclui as instituições públicas, como é o caso da Justiça do Trabalho, bem como destaca as ações de certos atores sociais diante da ofensiva contra direitos duramente conquistados em suas estratégias de resistência. Dessa forma, buscando trazer ao debate elementos sobre a relevância de um sistema público de proteção que contribua para com a construção de uma sociedade menos desigual, o texto aborda o contexto econômico das reformas liberalizantes nos dois países da América Latina: Brasil e Argentina, evidenciando a inconsistência

\footnotetext{
* Doutora em Economia; Professora do Programa de Pós-Graduação em Ciências Sociais da Universidade Estadual de Campinas (UNICAMP) e Pesquisadora colaboradora no Centro de Estudos Sindicais e de Economia do Trabalho (CESIT) da mesma universidade, Campinas, SP, Brasil; E-mail: magdabia@terra.com.br

** Doutora em Desenvolvimento Econômico; Pesquisadora colaboradora no Centro de Estudos Sindicais e de Economia do Trabalho da Universidade Estadual de Campinas (CESIT - UNICAMP), Campinas, SP, Brasil; E-mail: mari@uol.com.br
} 
da tese de que, diante do atual desenvolvimento do capitalismo, a reforma seria algo da ordem do "irreversível" em direção ao progresso e à realização da autonomia do indivíduo (Belluzzo, 2013). Discorrendo sobre o significado dessas reformas, o artigo destaca alguns de seus aspectos que evidenciam a tentativa de fragilizar a regulação pública, o papel das instituições que atuam no mundo do trabalho e as organizações sindicais. Por fim, depois de algumas considerações sobre os impactos da reforma nas negociações coletivas e nas estratégias de certos atores sociais na construção da resistência, chega às considerações finais.

Palavras chave: Reforma trabalhista; Direito do trabalho; Flexibilização; Centrais sindicais; Proteção social.

ABSTRACT: In this essay, we discuss the senses of Brazilian "labor reform", in vigour since November, 2017. We propose a dialog with ongoing reform in Argentina, seeking to demonstrate the fallacy of argues from its defenders. In this scenery, we also broach certain aspects of Brazilian reform and its impacts on the regulation system that includes public institutions, such as Labor Court. We also highlight the action of certain social actors face to the attack against rights hardly achieved in their strategies of resistance. Therefore, in attempt to bring to debate elements about the relevance of a public system of protection that must contribute to the construction of a less unequal society, we broach the economical context of liberalizing reforms in two countries from Latin America: Brazil and Argentina. We make evident the fallacy of the thesis that, face to current development of capitalism, the reform would be something "irreversible" toward the progress and achievement of individual autonomy (BELUZZO, 2013). We discourse about the meaning of these reforms and highlight some aspects that evidence the attempt to weaken public regulation, the role of institutions that act in the world of work and trade union organizations. Lastly, after some considerations on the impacts of the reforms on the collective bargaining and on the strategies of certain social actors in the construction of resistance paths, we reach the final considerations.

Keywords: Labor reform; Labor law; Flexibilization; Trade union; Social protection.

$\boldsymbol{R} \boldsymbol{E} \boldsymbol{S U M E}:$ L'article traite des sens de la "réforme du travail" brésilienne, en vigueur depuis novembre 2017, basée sur la dynamique de l'économie, dans un dialogue comparé à la réforme en cours en Argentine, en essayant de démontrer la fausseté des arguments de ses défenseurs. Dans ce scénario, l'article aborde certains aspects de cette réforme et son impact sur le système de réglementation qui inclut des institutions publiques, telles que la justice 
du travail, ainsi que souligner l'action de certains acteurs sociaux face à l'offensive contre les droits durement acquis dans leurs stratégies de résistance. Afin d'apporter au débat des éléments sur la pertinence d'un système de protection publique contribuant à l'édification d'une société moins inégalitaire, le texte aborde le contexte économique des réformes de libéralisation en cours dans les deux pays d'Amérique latine: le Brésil et l'Argentine, l'incohérence de la thèse selon laquelle, face au développement actuel du capitalisme, la réforme serait de l'ordre de "l'irréversible» vers le progrès et la réalisation de l'autonomie de l'individu (Belluzzo, 2013). A partir de la signification de ces réformes, l'article souligne certains de ses aspects qui mettent en évidence la tentative d'affaiblir la réglementation publique, le rôle des institutions actives dans le monde du travail et les syndicats. Enfin, après quelques considérations sur les impacts de la réforme sur la négociation collective et les stratégies de certains acteurs sociaux dans la construction de la résistance, nous en arrivons aux considérations finales.

Mots-clés: Réforme du travail; Droit du travail; Flexibilisation; Centrales syndicales; Protection sociale.

RESUMEN: El artículo discute los sentidos de la "reforma laboral" brasileña, vigente desde noviembre de 2017, a partir de la dinámica de la economía, en diálogo comparado con la reforma en curso en Argentina, buscando demostrar la falacia de los argumentos de sus defensores y, en ese escenario, que aborda ciertos aspectos de esa reforma y sus impactos en el sistema de regulación que incluye a las instituciones públicas, como es el caso de la Justicia del Trabajo, bien destacar las acciones de ciertos actores sociales ante la ofensiva contra derechos duramente conquistados en sus estrategias de resistencia. De esta forma, buscando traer al debate elementos sobre la relevancia de un sistema público de protección que contribuya a la construcción de una sociedad menos desigual, el texto aborda el contexto económico de las reformas liberalizadoras en los dos países de América Latina: Brasil y Argentina, evidenciando la falacia de la tesis de que, ante el actual desarrollo del capitalismo, la reforma sería algo del orden del "irreversible" hacia el progreso y la realización de la autonomía del individuo (Belluzzo, 2013). En el artículo destaca algunos de sus aspectos que evidencian el intento de debilitar la regulación pública, el papel de las instituciones que actúan en el mundo del trabajo y las organizaciones sindicales. Por último, algunas consideraciones sobre los impactos de la reforma en las negociaciones colectivas y en las estrategias de ciertos actores sociales en la construcción de caminos de resistência.

Palavras clave: Reforma laboral; Derecho laboral; Flexibilización; Centrales sindicales; Protección social. 
[...] Esse é o momento em que, tanto do ponto de vista prático, quanto ideológico e teórico, as classes dominantes e dirigentes, em escala mundial, aposta (e ganham) no retrocesso, no recuo das conquistas sociais e econômicas das classes subalternas. Não é de espantar que se observe a corrosão das instituições republicanas, que seja constante e reiterada a violação dos direitos sociais acumulados ao longo dos últimos trinta anos. [...] Difunde-se a ideia de que a liberação das forças que impulsionam a acumulação de capital é um movimento "natural" e "irreversível" em direção ao progresso e à realização da autonomia do indivíduo. (Luiz G. Belluzzo. O capital e suas metamorfoses, 2013, p. 33).

\section{INTRODUÇÃO}

Este artigo discute aspectos da aprovada "reforma trabalhista" brasileira, Lei $n^{\circ} 13.467 / 17$, vigente a partir de novembro de 2017, propondo-se a um diálogo comparado com a proposta de reforma encaminhada ao Parlamento pelo governo da Argentina em 2017, buscando, a partir da brasileira, descortinar, na dinâmica da economia, seus significados e impactos no sistema de regulação pública do trabalho, abordando, a partir desse cenário, as falácias de certos argumentos utilizados por seus defensores, bem como os caminhos de resistência de certos atores sociais.

Escrito em momento de aprofundamento das desigualdades no mundo e no Brasil ${ }^{3}$, está fundamentado em pesquisas desenvolvidas tanto no âmbito do projeto temático Contradições do trabalho no Brasil atual. Formalização, precariedade, terceirização e regulação, com apoio financeiro da Fundação de Amparo Pesquisa do Estado de São Paulo, FAPESP - Processo no 12/20408-1 -, quanto em estudos realizados no Centro de Estudos Sindicais e de Economia do Trabalho do Instituto de Economia da UNICAMP, CESIT, apresentados ao Ministério Público do Trabalho do Brasil, MPT, sobre os impactos da Reforma Trabalhista (Krein, Gimenez, Santos, 2018, pp. 209-242), compreendida a desconstrução da tela pública de proteção ao trabalho como uma das expressões do capitalismo

3 Segundo Thomas Piketty, enquanto em 1973 a população 1\% mais rica detinha $10 \%$ da renda, em 2013 passou a deter 20\% (Piketty, 2014). Sobre o aprofundamento das desigualdades consultar OXFAM 210. Informe, jan.2016. Disponível em: http://www.oxfam.org.br/sites/default/files/arquivos. Também: http://bit.ly/sfld 
contemporâneo, globalizado e hegemonizado pelos interesses das finanças, em que as cadeias de valor e as redes mundiais de produção redefinem as relações de trabalho, fragmentando a organização dos trabalhadores e impactando o sistema de regulação do trabalho que inclui as instituições republicanas que têm a incumbência de fiscalizar-lhes e de dar-lhes eficácia (Biavaschi, Teixeira, 2018).

Ressalvadas as especificidades de cada país, percebe-se que, em linhas gerais, os argumentos pró-reforma estão centrados em temas como (Krein, Gimenez, Santos, 2018, p. 210): necessária adequação da regulação do trabalho ao estágio atual do capitalismo e às novas tecnologias; retirada da "rigidez" da legislação trabalhista visando à sua "modernização"; supressão dos obstáculos ao "livre" encontro das vontades individuais para que, fortalecidas as negociações diretas entre patrões e empregados, seja ampliado o emprego e a produtividade; busca de maior "segurança jurídica", com medidas dirigidas à Justiça do Trabalho sob o argumento de que a excessiva judicialização dos conflitos é fator de insegurança, contribuindo para afastar investimentos externos. No caso das reformas efetivadas em países europeus, em que há direito ao emprego, a "retirada dos freios ao despedimento" (ibidem, p. 210) aparece de forma reiterada. Em síntese, as reformas estudadas nas pesquisas que fundamentam o presente texto (Krein, Gimenez, Santos, 2018), guardadas suas especificidades e sistemas jurídicos próprios, têm significado profundo ataque ao sistema de proteção social que inclui a regulação e as instituições públicas que atuam no mundo do trabalho. Desnudar as falácias desses argumentos é um dos objetivos do presente texto.

No Brasil desde os anos 2016 a crise econômica se aprofunda, com impactos alarmantes nos dados de desemprego e de informalidade. As tensões sociais intensificam-se à ação, grosso modo, de dois movimentos contrapostos: de um lado, os que defendem que desenvolvimento econômico e redução do desemprego são inviáveis nos marcos da Constituição de 1988, sendo necessário aprofundar os programas de ajuste fiscal, com fixação, por exemplo, de teto para o gasto público $^{4}$ e, para as relações de trabalho, com aprovação de propostas tados e do Senado Federal a Emenda Constitucional 95/2016 que instituiu no Brasil novo regime fiscal 
que invertam as fontes do direito do trabalho, atribuindo, entre outros temas, a prevalência do negociado sobre o legislado, e com ampliação das formas ditas "atípicas" de contratação, ampliada a terceirização para todas as atividades. Nesse campo estão economistas e estudiosos de corte liberal que apostam nessas reformas como via de incremento da produtividade e geração de postos de trabalho. De outro, estudiosos de distintas áreas do conhecimento que concluem não haver evidência teórica ou empírica de que contribua para aumentar a produtividade e a competitividade, contribuindo para aprofundar as iniquidades, precarizando ainda mais as relações de trabalho no País (Biavaschi, Santos, 2014, pp.19-35), corrente a qual este texto se filia.

Partindo dessa compreensão, o artigo discute os sentidos da "reforma trabalhista" brasileira, vigente desde novembro de 2017, a partir da dinâmica da economia, em diálogo comparado com a reforma em andamento na Argentina, buscando demonstrar a falácia de seus argumentos e, nesse cenário, abordar certos aspectos dessa reforma e seus impactos no sistema de regulação que inclui as instituições públicas, como é o caso da Justiça do Trabalho, bem como as ações de atores sociais diante da forte ofensiva contra direitos duramente conquistados em suas estratégias de resistência. Na Argentina, a reforma foi encaminhada ao Parlamento pelo Presidente Macri logo após a vigência da reforma brasileira, inclusive com o registro de que esta era referência e estímulo à proposição. No entanto, diante de expressivas manifestações de repúdio dos movimentos sociais e sindicais argentinos, sua tramitação foi suspensa, tendo o governo fatiado a proposição anterior visando a facilitar sua aprovação, como se abordará especificamente neste texto. Já no Brasil, ainda que tenha havido mobilizações coordenadas pelas Centrais Sindicais e pelo Fórum Interinstitucional em Defesa do Direito do Trabalho e da Previdência Social, FIDS, integrado por entidades do mundo jurídico, de representação da magistratura, do sistema de fiscalização e do meio sindical, como é o caso do Fórum Nacional em Defesa dos Direitos dos Trabalhadores Ameaçados pela Terceirização, Fórum, estas não foram suficientes para impedir sua aprovação em julho de 2017.

no âmbito dos Orçamentos Fiscal e da Seguridade Social da União por vinte exercícios financeiros. 
Sob o disfarce de falacioso discurso de modernização das relações de trabalho e aperfeiçoamento de regras para se ajustar ao momento atual do capitalismo e das transformações tecnológicas, trata-se de perverso e destrutivo desmonte dos direitos sociais duramente conquistados pelos trabalhadores brasileiros integrantes do sistema que regula as relações entre capital e trabalho sistematizado pela Consolidação das Leis do Trabalho, a CLT, de 1943, incorporado à Constituição Federal de 1988 na condição de direitos sociais fundamentais, cujo patamar civilizatório é ameaçado pela aprovação e vigência da Lei n. 13.429/17, de alto potencial mercantilizador das relações de trabalho. E o faz, por um lado, atribuindo o "livre" encontro das vontades "iguais" a condição de lócus privilegiado da produção das normas que regem aspectos fundamentais da relação capital e trabalho, avançando na "legitimação" de contratos de emprego simulados sob o rótulo de trabalho autônomo e na "legalização" de formas atípicas de contratação da força de trabalho, como é o caso do contrato intermitente e liberando a terceirização para todas as atividades, no âmbito público ou privado. Por outro, fragilizando o papel institucional da Justiça do Trabalho e dificultando seu acesso aos trabalhadores ao onerá-los com pagamento de honorários periciais e sucumbenciais que ferem o princípio da gratuidade. Por outro, ainda, atingindo brutalmente as organizações sindicais quer pela redução de suas atribuições, quer pela supressão abrupta de suas fontes de custeio, cuja constitucionalidade acabou de ser reconhecida pelo Supremo Tribunal Federal, STF, por seis votos a três, no julgamento da Ação Direta de Constitucionalidade, ADI $n^{\circ}$ 5794, e da Ação Direta de Constitucionalidade, ADC, $\mathrm{n}^{\circ}$ 55, apensada à primeira, sob o fundamento, em síntese, de que: a redução da influência do Estado e a facultatividade do recolhimento da contribuição proporcionarão maior liberdade sindical, fortalecendo as organizações sindicais. Importante, desde logo, sublinhar que essa reforma, tal como aprovada, abre a possibilidade à substituição dos empregados diretamente contratados por empresas prestadoras de serviços para a realização de quaisquer atividades. 
Sabe-se que o processo de construção dos direitos não se esgota no momento da aprovação das normas legais. Estas serão interpretadas o que, segundo melhor hermenêutica jurídica, deve ser feito em consonância com os princípios constitucionais e convencionais que regem a matéria (Grau, 2002). Ademais, este texto parte do suposto de que o direito, nível do todo social, é uma relação e as instituições públicas encarregadas de dar-lhes eficácia são condensações materiais de forças que expressam as lutas e as tensões que se dão em uma sociedade em determinado momento histórico (Poulantzas, 1990). E a interpretação que será dada aos artigos da "reforma" está em disputa, mesmo porque a fonte material das normas jurídicas se constitui no campo das lutas sociais. Daí a relevância de, em cenário normativo pós-reforma, indagar-se sobre estratégias dos atores sociais para refrear sua implementação, questionando-se o potencial de reversão dessas ações. Nesse sentido, quais as lições que se pode tirar da experiência Argentina, com expressivos movimentos sociais e sindicais que lograram obter a suspensão do andamento da reforma? Quais os caminhos que podem ser construídos no processo de resistência ao desmonte dos direitos duramente conquistados?

As tentativas de flexibilização direitos têm encontrado forte resistência junto às instituições de regulação do trabalho, às centrais sindicais, aos sindicatos e à classe trabalhadora. Não à toa, as reformas em discussão têm como alvo justo o sistema público de regulação e as instituições do trabalho incumbidas de fiscalizar e de assegurar sua aplicação. Essas instituições, com todas as suas dificuldades e contradições, têm sido obstáculo ao "livre" trânsito de um capitalismo sem peias que, movido por seu desejo insaciável de acumulação de riqueza abstrata, busca eliminar todos os obstáculos a esse "livre" trânsito (Belluzzo, 2013).

Discutir esse processo é de grande atualidade. Buscando trazer elementos que contribuam para com o debate sobre a relevância de um sistema público de proteção que contribua para com a construção de uma sociedade menos desigual, o texto aborda o contexto econômico das reformas liberalizantes nos dois países da América Latina: Brasil e Argentina, buscando evidenciar a falácia da tese de 
que, diante do atual desenvolvimento do capitalismo, a reforma seria algo da ordem do "irreversível" em direção ao progresso e à realização da autonomia do indivíduo (Belluzzo, 2013). Segue discorrendo sobre o significado das reformas, abordando alguns de seus aspectos que evidenciam a tentativa de fragilizar a regulação pública, o papel das instituições que atuam no mundo do trabalho e as organizações sindicais. Depois, traz considerações sobre os impactos da reforma nas negociações coletivas e as estratégias de certos atores sociais na busca da construção de caminhos de resistência, chegando às considerações finais.

\section{O CAPITALISMO CONTEMPORÂNEO E OS INTERES- SES DAS FINANÇAS}

A subordinação crescente do capital produtivo à lógica das finanças é uma das características distintivas do capitalismo neste último século. Sem fronteiras, ele arrasta os estados nacionais para uma intrincada rede de relações de poder e dominação, esvaziando o papel dos Estados e fragilizando ainda mais as políticas de proteção social e de direitos. Há autores que definem o atual período como os anos em que o Estado foi capturado pelos interesses das grandes corporações internacionais e aprisionado aos interesses do capital financeiro. (Belluzzo, Galípolo, 2017).

Nesse cenário se confrontam os interesses de acumulação de capital às necessidades sociais da população. A complexidade do capitalismo exige cada vez mais a presença de sistemas de regulação e instrumentos de natureza política fortes e coordenados pelos Estados e estes, por sua vez, assumem cada vez mais características associadas aos grandes interesses do capital, com a perda de autonomia e submetidos a uma lógica global extremamente perversa, especialmente depois da crise 2008.

Para Streeck, a desregulamentação a partir do fim dos anos de 1970 não atingiu somente os mercados de trabalho, mas os mercados de bens, serviços e capitais. Dessa forma, as pressões da concorrência serviram para piorar ou diferenciar cada vez mais os salários e as condições de trabalho. E os mercados de capitais transformaram-se, 
simultaneamente, em mercados para controle das empresas, tornando a maximização dos lucros o critério máximo de uma boa gestão empresarial (Streeck, 2013, p. 63). Esse processo de transformação impôs uma brutal concentração de capital sob a supremacia de uma minoria. Habermas (Habermas, 2005, p. 20), analisando as transformações do estado social dos anos de 1970, sugere que:

[...] os custos crescentes dos salários e os custos colaterais reforçam a tendência a investimentos na racionalização. Ora, eles, elevam a produtividade do trabalho e, ao mesmo tempo, reduzem o tempo de trabalho a tal ponto que, apesar da tendência secular à redução do tempo do trabalho, um número cada vez maior de operários é liberado. E, numa situação em que a própria esfera pública percebe a estagnação econômica, a escassez de investimentos, o aumento do desemprego e a crise dos orçamentos públicos como derivados dos custos do Estado do bem-estar social, é possível sentir as limitações estruturais inerentes ao projeto e à manutenção do Estado social”.

Ou seja, em suas análises Habermas prenunciou os dilemas que já estavam postos para os Estados nacionais que, desde os anos de 1980, vêm se transformando em instrumento das grandes corporações, cada vez mais endividados e reféns das pressões das instituições financeiras, FMI e Banco Mundial, com suas armadilhas de ajuste fiscal. As economias mundiais se defrontam com as pressões de um capitalismo cada vez mais hegemonizado pelos interesses das finanças e distante dos propósitos de garantir o bem-estar social. Como reflexo desse processo, que se acentuou a partir da crise de 2008, vê-se a ampliação da pobreza e o aprofundamento da desigualdade. Em 26 países de economia avançada a renda média caiu $2,4 \%$ entre 2008 e 2013. O relatório da OCDE de 2014 indica que o aumento persistente do desemprego em muitos dos países da OCDE tem exercido pressão considerável para a queda do crescimento do salário real. Com isso, tem ajudado a frear os custos unitários do trabalho e, por consequência, promove a competitividade externa em alguns países, em particular na zona do euro. (OCDE, 2014). 
O baixo salário é tratado como oportunidade de viabilizar a melhor estratégia para fomentar a disputa de mercados. É um jogo de soma zero porque se todos estão em busca dos mesmos resultados ninguém sai ganhando. Perdem a sociedade e a classe trabalhadora. Assim que funciona o sistema: o desenvolvimento do capitalismo desordena continuamente a organização das empresas. A força de trabalho é deslocada na medida em que certas qualificações se tornam desnecessárias. As empresas investem em estruturas que privilegiam empregos dominados por alta qualificação e alta produtividade e terceirizam as ocupações pouco qualificadas e de baixa produtividade e com isso excluem parcela dos trabalhadores da distribuição do crescimento da renda nacional (Rubery, 1978).

\subsection{Quando a lógica do capital domina o trabalho}

Se é verdadeiro que a natureza do emprego está mudando e o trabalho em tempo integral cada vez mais substituído por diversas outras formas de emprego, é também preciso reconhecer que esses empregos são dotados de elevado grau de competição, desvalorização das relações de solidariedade e intensificação de formas mais precárias de contratação, com implicações profundas na vida das pessoas pelo grau de insegurança e de incertezas que esses trabalhos parciais, intermitentes e precários oferecem em termos de futuro, além de contribuir para aprofundar as desigualdades. As principais tendências estão longe do padrão em tempo integral. Trata-se de uma gama de acordos contratuais independentes ou pseudo independentes. Segundo Atkinson (Atkinson, 2015, p.172), a diferença nos acordos de trabalho, em alguns casos, inclui não ser pago:

[...] No Reino Unido houve um crescimento rápido dos estágios sem remuneração, nos quais os jovens trabalham de graça esperando mais adiante garantir uma posição paga, e na quantidade de pessoas de contratos de zero hora, nos quais são considerados empregados, mas não têm horas garantidas e podem não ganhar nada em uma semana. 
É com profunda compreensão do movimento do capitalismo e do sentido das lutas que se travam por direitos que Belluzzo traz a ácida crítica à falsa ideia de que a liberação das forças que impulsionam a acumulação de capital seria um movimento "natural" e "irreversível" em direção ao progresso e à realização da autonomia do indivíduo (Belluzzo, 2013). O que se percebe é que, sob a justificativa das transformações que as novas tecnologias da informação e da comunicação ocasionam nas formas de contratação da força de trabalho, os que profetizam a necessidade de se ter empregos mais flexíveis parece que não se incomodam com o alto grau de precariedade resultante dessas novas modalidades. É que o ponto de partida é o mercado onde todos são potencialmente consumidores.

Nessa perspectiva, o trabalho deve se adaptar continuamente a essa lógica. Aliás, interessante o relato de Bauman (Bauman, 2008, pp.178) sobre a experiência de Arlie Russel Hochschild no Vale do Silício, EUA, em que a preferência por empregados "flutuantes", descomprometidos, flexíveis, "generalistas" e, em última instância, descartáveis, foi a mais seminal de suas descobertas. $\mathrm{O}$ empregado ideal seria alguém sem vínculos, compromissos ou ligações emocionais anteriores, e que evite estabelecê-los agora, disposto a assumir qualquer tarefa e sempre preparado para se ajustar de imediato e refocalizar suas próprias inclinações, abraçando novas prioridades e abandonando as adquiridas anteriormente.

Para Sundararajan $(2016)^{5}$, esses novos empregos são expressões de uma sociedade em movimento ao não distinguir esferas próprias entre trabalho formal e trabalho temporário, os torna indiferentes. Essas formas de trabalho exigem legislação pertinente que conciliem novos modelos com as antigas formas de trabalho, entendido como sendo o formalizado e realizado em tempo integral. Em geral, são abordagens que partem do pressuposto de que as mudanças tecnológicas são inevitáveis e que as novas ofertas de capital e trabalho - que aparecem de forma descentralizada, por meio de um grupo de pessoas, o que o autor define como "economia compartilhada" - torna indiferente os limites entre as esferas "pessoal" e "profissional", transformando as atividades rotineiras em mercadorias e/ou serviços.

5 Em The Sharing Economy - The End of Employment and the Rise of Crowd-based Capitalism. 
Porém, o que esses enfoques não mencionam é o grau de precarização e de insegurança que essas novas formas de alocação da força de trabalho promovem. Em uma sociedade cada vez mais mergulhada no mercado de consumo e com formas precárias de trabalho quem irá de fato consumir os seus produtos? Essa a pergunta que deve ser feita.

Experiências internacionais têm caminhado no sentido de uma maior flexibilização das formas de contratação, a exemplo da Espanha, em que o trabalho temporário cresceu de $14,8 \%$ para $26,5 \%$ ante o total de contratados, pari passu à queda da massa salarial, diante da reforma de 2012. O mesmo pode ser observado em relação a Portugal.

Em texto publicado em 2013 Atkinson alertara (Atkinson, 2013, p. 172) ${ }^{6}$ :

\section{$[\ldots]$}

Administrando funcionários e trabalhadores por contrato pela internet, as empresas agora têm a capacidade de transformar o trabalho em custo variável, em vez de fixo, ao envolver os trabalhadores conforme a necessidade. Nas nações [...] da OCDE, os empregos de meio período e temporários entre trabalhadores em idade ativa aumentaram de 1,5 a 2 vezes mais rápido do que o emprego total desde 1990 [...] em nossas próprias pesquisas sobre os empregadores dos Estados Unidos, mais de 1/3 disse que planeja aumentar o uso de trabalho eventual e de trabalhadores parciais nos anos vindouros, e vemos uma variedade de novos intermediários surgindo para suprir talentos de alta qualificação em atribuições de curto prazo.

Entre os que trabalham em tempo integral, um padrão de atividades múltiplas está se espalhando: o emprego fracionado, em que as empresas oferecem aos seus trabalhadores uma carteira de atividades, brindando-os com "fragmentos de tempo" (Atkinson, 2015). Segundo esse autor, [...] o jornal 'The Guardian' publicava um perfil de um possivel candidato ao parlamento que é assistente social em um hospital psiquiátrico beneficente, cuidador de um homem deficiente, funcionário de outra instituição, além de ser vereador (Atkinson, 2015, p. 173). 
Na maior parte das vezes, a discussão é colocada opondo as transformações organizacionais e tecnológicas à redução de empregos e apresentando como sendo "inevitáveis" adotar novas formas de contratação, as contratações atípicas. Mas o que os estudos mostram é que a segregação profissional aumentou ainda mais nas duas últimas décadas, com um enviesamento das competências face à mudança tecnológica (OIT, 2016). E o que distingue esse processo de reespacialização dos processos produtivos é a qualidade do emprego gerado na ponta, caracterizados por trabalhos informais, precários, em regra realizados nos domicílios.

Como se aprofundou nos estudos desenvolvidos no âmbito do CESIT/UNICAMP, que fundamentam este artigo, no México, por exemplo, as promessas de geração de emprego que acompanharam as reformas de 2012 não alcançaram êxito (Krein, Gimenez, Santos, 2018, pp. 209-242). As consequências da reforma mexicana podem ser tomadas como referência para o caso brasileiro. Aprovada com o beneplácito do setor empresarial, ela atingiu direitos e as organizações dos trabalhadores, sem resolver os problemas do mercado de trabalho mexicano, ao contrário. Entre aspectos dessa reforma destaca-se, por exemplo, a ampliação da terceirização e a redução de direitos dos trabalhadores, como fixação de limites às indenizações para os casos de despedidas sem justa causa. ${ }^{7}$ Ainda que essas medidas tenham sido introduzidas mediante promessa de redução do desemprego, esse problema não foi atacado. Ao contrário, houve queda no ritmo de criação dos empregos protegidos, com manutenção do déficit de empregos, aumento do trabalho de curta duração, além da ampliação dos empregados em microunidades (menos de 5 trabalhadores). As microunidades - que incluem o trabalho por conta própria - representam $51 \%$ da força de trabalho urbana. É verdadeiro que essas tendências existiam na economia mexicana, porém foram reforçadas com reforma similar

\footnotetext{
7 Disponível em : http://dof.gob.mx/nota_detalle.php?codigo=5280815\&fecha=30/11/2012. A reforma estabeleceu limite para o pagamento dessas indenizações por um ano e a juros mensais para os anos seguintes de $2 \%$ sobre a base de 15 meses, o que equivale a aproximadamente $30 \%$ do salário, sob o argumento de que as Juntas de Conciliação e Arbitragem são muito lentas. Outra mudança foi o "contrato por prova", em que o trabalhador dispensado com menos de seis meses não tem direito à indenização. Por outro lado, dispositivos dificultaram greves, com cortes de salário e prazo de no mínimo dez dias de antecedência para a greve ser informada. Como a brasileira, as jornadas e seus horários podem ser flexíveis, com permissão de pagamento apenas das horas trabalhadas.
} 
à brasileira, com perda de direitos (Salas, 2013). Os salários foram reduzidos $^{8}$ e a reforma gerou insegurança, queda no consumo, redução do poder de compra e aumento da instabilidade e da violência.

Essas tendências de flexibilização estão presentes desde os anos de 1970. Nos países latinoamericanos, a partir dos anos de 1980 e 1990 aparecem como resposta ao processo cada vez mais intenso de integração das economias à lógica de inserção internacional e de construção de um sistema de relações de trabalho competitivo que subjuga os trabalhadores a padrões salariais e condições de trabalho vigentes em determinados países, condenando-se a maior parte dessas sociedades a um futuro de miséria e de aprofundamento das desigualdades. Os dados expressam essa realidade.

\subsection{As novas tecnologias e a regulação pública do trabalho}

As inovações tecnológicas vêm gerando mudanças na produção industrial desde o início do século XX. O elemento novo nesse processo é a economia digitalizada, considerada a grande responsável pelas transformações na produção da forma como a conhecemos hoje. O termo "indústria 4.0" ou quarta revolução industrial está associado às pesquisas de alta tecnologia realizadas, inicialmente, pela Alemanha. Desde então, esse termo "Indústria 4.0" - ou quarta revolução industrial - passou a ser utilizado de forma indistinta e ampla, primeiramente pelo Fórum Econômico Mundial, em 2015, estendendo-se para publicações - ex: o The Economist publicou número especial sobre a "Indústria 4.0" e a Eurofound, agência de pesquisa da União Europeia, produziu informes sobre as consequências da quarta revolução industrial para o futuro do trabalho. Portanto, a quarta revolução industrial designa a adoção de tecnologia que represente avanços, rompendo com padrões e modelos estabelecidos, a exemplo da digitalização e da inteligência artificial.

Os conceitos abarcam desde empresas que se utilizam internet para oferecer soluções personalizadas, passando por prestadores de serviços indiretos por meio de plataformas, até o uso das mais

$882 \%$ da PEA recebe menos do que 100 pesos diários, equivalente a aproximadamente US\$ 5,00 ou R\$ 18,00 . 
variadas formas de tecnologias, como impressão 3D, drones, robótica industrial avançada, entre outros, em combinação com o desenvolvimento nas áreas de engenharia, biotecnologia, nanotecnologia e microtecnologia, materiais avançados e mudanças radicais aplicadas em tecnologias energéticas e meio ambiente. A inteligência artificial, por exemplo, representa estágio em que as máquinas são capazes de comunicar-se entre si ao invés de se reportarem para um painel de controle operado por empregados qualificados. Essas mudanças estão alterando profundamente os padrões de produção e consumo, mas também de nossa relação com a sustentabilidade da vida humana e da própria relação com o trabalho.

Por outro lado, as previsões referentes à quarta revolução industrial e seus impactos no mercado de trabalho aparecem na literatura de forma bastante polarizada. As expectativas otimistas vislumbram possibilidades de ampliação da quantidade de trabalho com altos salários. Já os diagnósticos mais pessimistas preveem perdas de empregos entre $35 \%$ a $45 \%$. A OCDE estima que $9 \%$ dos empregos estarão em risco e de que $50 \%$ a $70 \%$ das tarefas serão automatizadas, enquanto a OIT sugere, em estudo, que 56\% dos empregos correm risco de automatização nos próximos 20 anos. É muito difícil avançar em dados concretos porque são muitos os fatores que afetam ou podem afetar esse processo em transformação. Ocorre que as sociedades estão em constante transformação e à ação dos sujeitos sociais em luta. Determinar o ritmo dessas mudanças e como afetará o conjunto das economias desenvolvidas e não desenvolvidas faz parte da complexidade do momento histórico que estamos vivendo. Sabese que historicamente o capital nunca prescindiu do trabalho, seja como ofertante de força de trabalho ou consumidor de seus produtos.

Nesse contexto, a descentralização produtiva - que está na base do modelo- cresce com as plataformas virtuais, criando oligopólios na prestação de serviços, a exemplo do Uber. O fenômeno da "uberização" vem sendo estudado com muita preocupação9. Sendo correto afirmar que uma das características constitutivas da atual etapa do

9 Ver a respeito ABILIO, L. C. Uberização: subsunção real da viração Blog da Boitempo, fevereiro de 2017 disponível em: https://www.google.com.br/amp/s/blogdaboitempo.com.br/2017/02/22/ uberizacao-do-trabalho-subsuncao-real-da-viracao/amp/ 
capitalismo está na subordinação crescente dos avanços tecnológicos aos interesses exclusivos do capital produtivo e financeiro, não menos correta é a constatação de que se trata de um processo histórico cujo resultado ou desfecho dependerá da correlação de forças sociais em disputa. Para os que partem do suposto de que os avanços tecnológicos devem estar a serviço da sustentabilidade da vida, a pergunta que se coloca é quem se apropriará dos benefícios desses avanços: será o capital privado ou essa apropriação se dará para a produção de bens públicos que tenham condição de melhorar e vida em coletividade? Daí a relevância de ser retomada a capacidade de o Estado atuar como impulsionador do desenvolvimento econômico, com políticas de fomento à pesquisa e de projetos alicerçados em regulação pública que estabeleça as condições em que as pesquisas tecnológicas devam ser desenvolvidas e como seus resultados possam ser apropriados pela sociedade visando ao bem comum.

Em um Brasil submetido a duro programa de austeridade fiscal introduzido pela Emenda Constitucional 95, aprovada logo depois do impeachment da Presidenta Dilma Rousseff, a economia está em frangalhos. Como frutos do aprofundamento dessa política de austeridade fiscal e de subordinação ao rentismo, mais de 13 milhões de brasileiros estão desempregados e grande parcela dos ocupados exerce trabalhos precários. Portanto, não são as tecnologias que estão desempregando. Certamente, trata-se de uma das expressões dos equívocos da política econômica neoliberal que afeta a sociedade como um todo e, de forma mais contundente, as mulheres e a população negra, maioria entre as pessoas desempregadas e nos trabalhos sem proteção social.

\section{O CONTEXTO DAS REFORMAS LIBERALIZANTES NOS DOIS PAÍSES}

Desde o impeachment da Presidenta Dilma Rousseff, em 2016, o governo brasileiro passou a adotar medidas de aprofundamento da austeridade fiscal. A Emenda ${ }^{\circ}$ 95, aprovada no Senado em 15 de dezembro de 2016, introduziu congelamento do gasto público por vinte anos, incluindo despesas com saúde e educação, permitindo correção 
apenas pela inflação. Algo "internacionalmente inédito" e antagônico à Constituição Federal de 1988 (Rossi, Mello, 2017). Essa aprovação se deu sem qualquer proposta ou promessa de mudança no regressivo sistema tributário que "penaliza os pobres e beneficia os ricos" (ibidem, 2017), sem tocar nas desonerações, sonegações, remessas de dinheiro para paraísos fiscais e sem debater, à época, os elevados juros nominais que, então, correspondiam a mais "de $8 \%$ do PIB, ou seja, mais ou menos o valor gasto com o sistema de seguridade social" (ibidem, 2017). Essa política de ajuste fiscal em combinação com os impactos nos investimentos paralisados em toda a cadeia produtiva do petróleo e na construção civil desencadearam redução brutal no nível de atividade econômica. Nesse cenário, as famílias de baixa classe média e da classe trabalhadora são as que mais sofrem, extrato que concentra os maiores índices de desocupação: 86\% do desemprego está concentrado nesses extratos e mais de $68 \%$ dos desempregados são negros e mais de $54 \%$ mulheres. Trata-se de uma crise que afeta a população mais pobre, negra e vulnerável.

Além de outras medidas que ferem a soberania do país, o governo deu andamento à reforma da Previdência, até hoje resistida, e fez aprovar, em março de 2017, projeto de lei esquecido nos escaninhos da Câmara, que, tratando do trabalho temporário, dava margem à adoção da terceirização irrestrita; e, em 23 de dezembro de 2016, encaminhou a "reforma trabalhista", objeto do presente artigo.

Quanto ao contexto em que criadas as condições para a aprovação dessa reforma trabalhista, é importante destacar que no dia 23 de dezembro de 2016 o Governo Temer apresentou ao Parlamento proposta expressa no PL 6.787/2016 centrada, sobretudo, na ideia da supremacia do negociado sobre o legislado. Ou seja, o encontro das vontades coletivas, de forma prevalente, passaria a ser o lócus de produção das normas destinadas às relações entre capital e trabalho, sendo invertido o sistema das fontes do Direito do Trabalho para ser colocado em segundo plano aquele patamar mínimo civilizatório representado pela lei, cuja universalidade é característica essencial. $\mathrm{O}$ argumento então adotado, em síntese, foi o de que a reforma seria imprescindível para "modernizar" a legislação trabalhista brasileira 
retirando-lhe a "rigidez" impeditiva da geração de empregos e de retomada da atividade produtiva (Biavaschi, Teixeira, 2018).

Essa ênfase à "modernização" e à retirada da "rigidez" já aparecera em 2012, com algumas variações, no documento da Confederação Nacional da Indústria, $\mathrm{CNI}^{10} \mathrm{e}$, a seguir, no da Confederação Nacional do Agronegócio, CNA. Em 2015, o partido do então Vice Presidente Temer, o PMDB (hoje MDB), apresentou o programa Uma ponte para o futuro, no qual igualmente apontava para a necessidade de serem alteradas as fontes do Direito do Trabalho, com supremacia do negociado sobre o legislado, e de ser adotado rigoroso programa de ajuste fiscal como condicionante à geração de emprego, à retomada do crescimento e à superação da crise econômica.

Em 03 de fevereiro de 2017, ato da Presidência da Câmara dos Deputados criou Comissão Especial para proferir parecer ao referido PL 6.787/16. Após audiências públicas realizadas, em 12 de abril de 2017 o relator, deputado Rogério Marinho (PSDB-RN), apresentou seu parecer, trazendo versão totalmente nova ao texto original. Para além do negociado sobre o legislado, estruturou a proposta na ideia do "livre encontro" das vontades individuais, dando ênfase ao tema da segurança jurídica, responsabilizando a Justiça do Trabalho pela geração de insegurança aos investidores. Aprovada pela Câmara dos Deputados e encaminhada ao Senado da República, a proposta teve tramitação relâmpago, sendo aprovado com precária discussão com a sociedade.

Contrapondo-se à ideia de um Estado indutor do crescimento econômico e promotor de políticas sociais inclusivas (Rossi, Mello, 2017), como salientam as pesquisas que fundamentam este texto (Biavaschi, Teixeira, 2018), a reforma introduziu mudança radical do sistema de regulação do trabalho no Brasil, representando verdadeiro regresso a tempos anteriores ao processo de industrialização brasileira iniciado, de forma sistemática, a partir de 1930. Aspectos estruturantes da CLT foram alterados. O sistema público de regulação foi atingido, incluída a fiscalização, a Justiça do Trabalho e a organização sindical.

Assim que a reforma trabalhista entrou em vigência no Brasil, aprovada pelo Senado em 11 de julho de 2017 para viger em 10101 propostas para modernização trabalhista, CNI, Brasília, 2012. Disponível em: http://www. abinee.org.br/informac/arquivos/cniprop.pdf. 
novembro de 2017, o Presidente Macri encaminhou ao Congresso Nacional da Argentina, em 17 de novembro daquele ano, o projeto titulado "Anteprojeto de reforma laboral", em vários aspectos assemelhado à lei brasileira, referenciando, inclusive, ao caso brasileiro como exemplo e fazendo uso dos mesmos argumentos. Macri fora eleito em 2015 com plataforma ultraliberal. Seus primeiros anos de governo foram marcados por forte retrocesso econômico e social, inflação elevada, dívida externa crescente, aumento do desemprego e das desigualdades sociais. De acordo com dados do INDEC $^{11}$, no segundo semestre de 2017 o percentual de pessoas abaixo da linha de pobreza era de $25,7 \%$. Como resultado das políticas de ajuste houve forte contração da atividade econômica, elevação do desemprego para próximo de dois dígitos (9,1\% em 2018) e inflação anual de 26,0\% (dados do IPC de maio de 2018), tal como acontecera no Brasil cujas políticas de austeridade adotadas em 2016 elevaram a taxa de desemprego de 4,8\% em 2014 para mais de 13,1\% no primeiro trimestre de 2018, segundo dados do IBGE.

Foi nesse universo que as reformas de corte neoliberal foram propostas, inseridas em um contexto mais geral de desmonte do Estado e das políticas públicas abrindo caminho, dessa forma, à redução de carga tributária em favor do capital, redução do papel do estado e mercantilização de bens públicos, como saúde, educação previdência e moradia. No caso da "reforma trabalhista", os argumentos e as promessas que fundamentam o projeto brasileiro e o argentino são equivalentes: diminuir o déficit fiscal, promover investimentos, gerar empregos, melhorar a competitividade, combater a informalidade e recuperar as contas do sistema de seguridade social. Desde 2015, a política econômica argentina vem sendo conduzida pelos preceitos neoliberais, tal como no Brasil pós-impeachment de 2016.

As pressões pela flexibilização se intensificaram nos últimos anos como forma de as empresas se adaptarem, em parte, a um contexto de menor retorno sobre os investimentos realizados e em parte porque os rendimentos do trabalho vinham superando os ganhos do capital, com a melhoria da distribuição de renda. Soma-se a isso, as mudanças de caráter 
estrutural e a reestruturação nos processos organizacionais, por meio da racionalização do uso do tempo: diante de uma demanda cada vez mais instável e irregular, é fundamental para o capital dispor da força de trabalho em tempo integral, ajustando as formas de contratação e dispensa, jornada, férias, de acordo com as suas necessidades e com isso eliminando os tempos mortos e os direitos consagrados pela legislação trabalhista, que passa a ser entendida como um entrave ao capital.

Quando se observa o debate público brasileiro, vê-se que, já em momento anterior ao impeachment, a austeridade fiscal era enfatizada como necessária pelas elites econômicas e financeiras do país, definida como política de ajuste fundada na redução dos gastos públicos e do papel do Estado, sob o argumento de que, diante do contexto de crise econômica e de aumento da dívida pública, a austeridade é a saída necessária, constituindo a base da defesa das reformas estruturais apresentadas. Ou, no dizer de Belluzzo, difunde-se “.... ideia de que a liberação das forças que impulsionam a acumulação de capital é um movimento "natural" e "irreversível" em direção ao progresso e à realização da autonomia do indivíduo". (Belluzzo, 2013, p. 33). É com essa visão que tem sido conduzida a política econômica desde 2016.

Nesse processo, os temas do custo do trabalho e da insegurança jurídica são vastamente invocados pelos defensores da reforma. Sustentando que o descompasso entre crescimento da produtividade e dos salários é incompatível com o padrão de retomada da atividade econômica e do emprego, atribuem o aumento do desemprego à ausência de mecanismos regulatórios que possibilitem maior flexibilidade na contratação, remuneração e uso da força de trabalho, que limitem a ação da Justiça do Trabalho e do sistema de fiscalização e, inclusive, o papel dos sindicatos. Um dos aspectos centrais das reformas é a regulamentação da terceirização ampliando-a para todas as atividades. A terceirização constituiu uma forma de desregulamentação das relações de trabalho, ao permitir um rebaixamento nos salários, nas condições de trabalho, na segurança do trabalho, ao ampliar a liberdade da empresa na determinação das condições de contratação e remuneração do trabalho, além de promover uma segmentação da representação sindical. Na Argentina, a proposta de reforma laboral 
propõe eliminar a responsabilidade solidária para um conjunto de atividades e introduz duas modalidades de contratação que atualmente são consideradas fraudulentas: trabalhador autônomo economicamente dependente e trabalhadores independentes como colaboradores; o projeto estimula que estas formas de contratação sejam adotadas em substituição às contratações sem registro. (Tomada, 2017).

Entretanto, quando se olha para o Brasil passados mais de seis meses da entrada em vigor da reforma, o que se vê é a manutenção de elevado desemprego e o aprofundamento da precariedade em face das novas formas de contratação que a reforma legitima, a exemplo do contrato intermitente e parcial. Inclusive, os dados de judicialização dos conflitos trabalhistas que caíram vertiginosamente logo após a vigência da "reforma", já iniciam, segundo dados do TST, a crescer novamente, embora não haja ainda um tempo suficiente para se apontar para tendência nesse sentido.

Na Argentina, a partir de 2016, acentuou-se o déficit na balança comercial, promovendo profunda crise cambial e financeira. Por outro lado, o preço das tarifas públicas básicas disparou, afetando os mais pobres e os que vivem de salários, em cenário de forte aumento da inflação e da pobreza. O déficit na balança comercial provocado pela política de abertura comercial e o crescimento das importações foi contrabalanceado com a atração de capital especulativo em face dos juros extremamente atrativos, superiores a $27 \%{ }^{12}$ ao ano. Com isso, intensificou-se o endividamento externo e promoveu-se a renegociação da dívida externa com o FMI. Em oposição a essa política e às reformas laborais, as três Centrais Sindicais argentinas, com amplo apoio da sociedade, convocaram greve geral para o dia 25 de junho de 2018, extremamente exitosa ${ }^{13}$. Trata-se da terceira greve geral desde a posse do presidente Macri.

Os estudos sobre o tema, abordados nos trabalhos do CESIT que fundamentam este texto, e as experiências internacionais amplamente divulgadas, reforçam os argumentos de que países que se utilizaram

12 El Pais. https://brasil.elpais.com/brasil/2017/10/19/internacional/1508440676_071292.html. Acessado em 25/06/2018.

13 A greve geral paralisou bancos, postos de gasolina, escolas e universidades, atendimentos não urgentes em hospitais, portos, serviços de limpeza urbana e de transportes, incluindo o setor aéreo. https://www.nexojornal.com.br/expresso/2018/06/29/Os-3-momentos-de-greve-geral-contra-o-governo-Macri-na-Argentina. 
de mecanismos de desregulamentação do trabalho não ampliaram seus níveis de emprego e nem mesmo melhoram seu desempenho econômi$\mathrm{co}^{14}$. Do ponto de vista macroeconômico, as estratégias de flexibilização acentuam de forma mais rápida a destruição de postos de trabalho em períodos de crise, de forma que a retomada da atividade econômica num segundo momento não será suficiente para repor estes empregos ${ }^{15}$.

O que é preciso sublinhar é que quando são reduzidos os empregos formais ampliam-se as inseguranças e a precariedade com forte impacto sobre a renda do trabalho e o mercado de consumo que, ao se estreitar pela ausência de demanda forçará, necessariamente, um processo de reconcentração de renda em mãos do capital comprometendo o próprio desenvolvimento. São os trabalhadores que gastam o que ganham. Sob outra perspectiva, a precariedade do emprego se acentua com maiores níveis de pobreza e é um fator de desmotivação para os próprios trabalhadores, que serão empurrados de um emprego para outro sem criar vínculos com nenhuma forma de trabalho; além disso, os contratos intermitentes mascaram vínculos precários que podem chegar a 4,8 ou 16 horas semanais e salários proporcionais.

$\mathrm{O}$ impacto também pode ser medido nas próprias empresas com queda brutal do consumo, o que implica que setores inteiros, por ausência de mercado de consumo, deixem de produzir internamente e migrem para outros mercados mais rentáveis. Se não há mercado para os seus produtos não haverá novos investimentos. Paradoxalmente, se para impulsionar o mercado competitivo é necessário reduzir direitos e salários e se todas as empresas seguem o mesmocaminho, conforme Lipietz ${ }^{16}$ argumenta (1994), o que teremos como principal efeito será a perda de mercado interno para a recessão e redução do poder de compra da maioria da população.

Finalmente, diferentemente do discurso modernizador defendido pelos setores empresariais, não há nenhuma possibilidade de que as Negociações Coletivas se fortaleçam com a aprovação do "negociado sobre o legislado". No Brasil, ampla legislação regulava

14 http://www.ilo.org/wcmsp5/groups/public/---dgreports/---dcomm/---publ/documents/publication/wcms_443480.pdf

15 http://www.scielo.org.mx/scielo.php?script=sci_arttext\&pid=S0186-10422010000200003

16 "La flexibilidad laboral". Revista Doxa, 1541, entrevista realizada por Ana Dinerstein y Silvio Santantonio. 29-31, 1994. 
as relações de trabalho, protegendo os trabalhadores com a garantia de direitos mínimos expressos na CLT e na Constituição de 1988. Os Acordos ou as Convenções Coletivas historicamente têm como objetivo elevar os patamares civilizatórios mínimos expressos na lei, ampliando a proteção social, fortalecendo o instituto da negociação, a representação sindical e a própria classe trabalhadora.

A possibilidade de renúncia a direitos pela via da flexibilização que a supremacia do negociado sobre o legislado pode significar, ao contrário do propalado pelos defensores da ideia, fragmenta a organização dos trabalhadores e a luta sindical. No limite, poderá haver Acordos por empresa em um contexto em que as práticas antissindicais, perseguição a dirigentes sindicais e desrespeito à organização sindical é uma realidade. Abordar elementos dessas reformas e as estratégias de resistência dos atores sindicais é um dos objetivos deste texto.

\subsection{Alguns aspectos das reformas do Brasil e da Argentina}

Como já sublinhado, a essência da reforma trabalhista brasileira está em alterar o sistema das fontes do Direito do Trabalho para, afastando a regulação pública que se contrapõe ao princípio da autonomia da vontade das partes, dar prevalência ao "livre" encontro das vontades individuais dos empregados e dos empregadores como espaço apto a produzir as normas que regerão as relações entre compradores e vendedores da força de trabalho. Com isso, é desmontada a tela pública que fundamenta o sistema de relações de trabalho (Biavaschi, 2017, pp.183-184).

Para além das formas de contratação já previstas em lei, é proposta a reedição do contrato em tempo parcial que poderá variar entre 26 e 30 horas semanais; o contrato intermitente, com alternância de períodos de prestação de serviços; o contrato de autônomo com exclusividade; teletrabalho sem controle de jornada. Além disso, a jornada poderá alcançar 12 horas diárias; com o banco de horas, a compensação de jornada poderá ser firmada individualmente; o horário de almoço poderá ser reduzido para 30 minutos; os feriados poderão ser alterados para evitar as pontes; as férias poderão ser parceladas em 
três períodos; os acordos salariais poderão ser individuais por meio da livre negociação; os salários poderão ser calculados por produtividade individual; planos de carreira e acesso a promoção também poderão ser individualizados, aprofundando a já heterogeneidade do mercado de trabalho. Desde que autorizado, mulher gestante e lactante poderá trabalhar em ambiente insalubre, assim como a jornada para aqueles que trabalham em ambientes insalubres poderá ser ampliada sem previa licença das autoridades. A rescisão do contrato de emprego, desde que ajustada entre empregado e empregador, representará pagamento de metade das verbas rescisórias e redução do acesso ao FGTS, o trabalhador e a trabalhadora serão obrigados ao final de cada ano a dar quitação dos valores recebidos ao longo do ano, coagindo-os sob o risco de serem demitidos no caso de recusa.

Ou seja, são medidas que alteram profundamente as relações de trabalho, retiram direitos, intensificam a jornada e o ritmo do trabalho, expõem os trabalhadores a condições de insegurança com forte impacto à saúde e à segurança no trabalho, individualizam as relações entre os compradores e vendedores da força de trabalho ao retirar a prevalência das normas pública de proteção, ampliando o controle do capital sobre o trabalho. Como resultado, teremos um trabalho submisso e sem controle de jornada e de remuneração, dois aspectos fundamentais das relações de trabalho. Além de retirarem direitos, a reforma introduz medidas que atingem a Justiça do Trabalho na sua função primeira de assegurar a eficácia da tela pública de proteção, afetando o sistema de fiscalização e fragilizando a ação coletiva dos trabalhadores quer pela redução de seu papel, quer por meio do fim do imposto sindical. Este, segundo a lei, só poderá ser descontado do trabalhador que o autorizar por escrito. Essa alteração da sustentação financeira das entidades sindicais, recentemente declarada constitucional pelo STF, não tem como objetivo fortalecer a representação dos trabalhadores como argumentaram alguns dos Ministros do STF, mas, sim, desestruturá-la para que não se constitua em força política capaz de reagir à retirada de direitos, enfraquecendo a ação sindical na luta contra a flexibilização de direitos e contra o desmonte social (Biavaschi; Teixeira, 2018, mimeo) e comprome- 
tendo o futuro do trabalho e o acesso à previdência pública. Aliás, esse impacto negativo na previdência está demonstrado no capítulo 9 da pesquisa realizada no âmbito do CESIT/Unicamp ao simular os impactos do aumento da "pejotização" (Krein, Gimenez, Santos, 2018, pp. 275-302), com contratação via MEI de “empresários”, na realidade empregados disfarçados, impondo decorrente redução das contribuições ao fundo público. Conforme dados da ANFIP de 2014, $51 \%$ do financiamento da seguridade social advém da massa salarial. Trata-se de contratos que carregam elevado grau de precariedade a exemplo dos temporários, intermitentes, parciais, terceirizados e firmados com pessoas jurídicas (PJs) com significativa queda na arrecadação. Além disso, por se tratar de contratos precários, haverá maior exposição a longos períodos de desemprego e retorno ao mercado de trabalho em condições mais desfavoráveis e com salários menores. O resultado disso será uma sociedade sem futuro.

É nesse sentido que se afirma que a "reforma trabalhista" brasileira, tal como aprovada (aliás, por lei infraconstitucional), apresenta conteúdo que regride aos patamares do Código Civil Brasileiro de 1916. Esse regresso fica claro, por exemplo, quando impõe aos juízes e aos Tribunais que se limitem a aplicar somente os "aspectos formais da manifestação de vontade, ainda que os instrumentos decorrentes da negociação coletiva violem os princípios do não retrocesso social e da estabilidade das relações sociais" (Teixeira, et. all., 2017). Portanto, a reforma tem como um de seus objetivos fragilizar a atuação da Justiça do Trabalho cujas decisões, de forma majoritária, compreendem a CLT e a Constituição de 1988 à luz de seus princípios, dando prevalência às negociações coletivas desde que respeitado o patamar mínimo civilizatório conquistado. E assim fazendo, a lei reforma abandona os fundamentos da República inscritos na Constituição de 1988 (artigo $1^{\circ}$, III e IV e artigo $3^{\circ}$, I, III, IV), na contramão da caminhada redutora das desigualdades sociais. Daí a necessidade de que seja interpretada e aplicada em consonância com os princípios constitucionais e convencionais que regem a matéria, tendo-se claro que o direito, nível do todo social, não se interpreta em tiras (Grau, 2002). 
Por outro lado, quando se analisam as motivações econômicas da reforma evidenciam-se as falácias desnudadas, como já abordado no item referente à dinâmica econômico. Essas falácias são desnudadas, sobretudo, quando se analisam os dados referentes ao desempenho da economia brasileira em período recente, em que houve crescimento econômico, elevação da renda do trabalho, formalização dos contratos e baixo desemprego estando em vigor essa mesma tela de direitos responsabilizada pelo desemprego e pela insegurança. Na realidade, a reforma objetiva atingir a regulação e as instituições públicas, especificamente a Justiça do Trabalho, introduzindo impedimentos ao seu acesso. Por outro lado, a litigiosidade não decorre do detalhamento acentuado das obrigações trabalhistas, mas do descumprimento sistemático das normas de proteção ao trabalho. Esse incremento de demandas se dá pari passu ao aumento das despedidas e dos descumprimentos à legislação, em um país em que as baixas penalidades não desestimulam a lesão a direitos.

Como evidenciam os dados do Tribunal Superior do Trabalho, TST, e do Conselho Nacional de Justiça, CNJ, grande parte das reclamatórias busca o pagamento de parcelas devidas nas despedidas, horas extras e reconhecimento do vínculo de emprego burlado. Portanto, a segurança jurídica almejada é a liberdade de descumprir a tela mínima de proteção ao trabalho, deixando o trabalhador em absoluta insegurança e instabilidade.

Dizem os defensores da reforma, que a CLT e a Justiça do Trabalho são responsáveis pela litigiosidade crescente, argumentando que os conteúdos da regulação e das decisões judiciais estimulam a litigiosidade, produzindo insegurança. Daí as medidas que colocam obstáculos às reclamações, exigindo, por exemplo, pagamento de custas pelo reclamante quando o processo é arquivado por ausência injustificada à audiência, mesmo sendo beneficiário da Justiça Gratuita, o que afeta o sistema e inviabiliza a concretização da garantia constitucional de acesso ao Judiciário. Na mesma linha, a sucumbência recíproca, com condenação em honorários do advogado da parte contrária e possibilidade de dedução do valor correspondente do crédito reconhecido judicialmente. 
Dados do CNJ e do TST evidenciam a falácia dos argumentos justificadores dessas medidas, como evidencia o capítulo 7 do livro "Dimensões Críticas da Reforma Trabalhista no Brasil", já referido (Krein, Gimenez, Santos, 2018, pp. 209-242). ${ }^{17}$ Quando se olha o número dos processos não solucionados, os dados mostram que a Justiça Estadual é responsável por 79,2\% dos processos pendentes; a Federal por $12,6 \%$, a Trabalhista $6,8 \%$. A série histórica dos processos novos demonstra aumento em quase todos os segmentos, à exceção dos Tribunais Superiores e da Justiça Militar Estadual, evidenciando que, no período como um todo, o crescimento da demanda foi de 19,2\%, apesar das reduções pontuais em 2010 e 2015. Em apenas um ano, entre 2015 e 2016, o número de decisões cresceu 11,4\%, enquanto o crescimento acumulado dos seis anos anteriores foi de $16,6 \%$. Tal incremento chegou a 30,8 milhões de casos julgados em 2016.

Em relação aos processos novos ajuizados, o maior número não está na Justiça do Trabalho. A Justiça Estadual foi responsável por $68,1 \%$ das novas ações em 2016, enquanto a Justiça do Trabalho recebeu 13,3\% dos novos processos, seguida da Justiça Federal que recebeu no período o correspondente a $12,9 \%$ dos novos ajuizados. Ou seja, o invocado excesso de judicialização em relação à Justiça do Trabalho, quando comparada com os demais ramos do Judiciário, não se sustenta. Já os dados gerais dos ajuizamentos na Justiça do Trabalho mostram que estes têm crescido sistematicamente desde 1988 até 2016, com exceção de 2010 em que o percentual foi negativo e que, depois de certa estabilização, voltou a crescer no ano de 2015.

Mas o que é relevante para a discussão aqui travada é o exame do conteúdo das ações judiciais. Segundo dados do CNJ mais de $60 \%$

17 É importante referir que de 2008 a 2013 o número de magistrados por habitante era crescente, subindo de 1,75 por 100 mil habitantes em 2008 para 2, $04 \mathrm{em} \mathrm{2012.} \mathrm{No} \mathrm{entanto,} \mathrm{a} \mathrm{partir} \mathrm{de} 2013$ começa a decrescer, baixando para 1,97; em 2014 para 1,95; em 2015 para 1,93; e em 2017 para 1,92 por mil habitantes, deixando claro o paulatino desaparelhamento e a sobrecarga da instituição. Enquanto isso, o número de processos aumentou. Em 2016, eram 79,7 milhões de processos aguardando solução definitiva. Destes, 13,1 milhões, ou seja, 16,4\%, estavam suspensos ou sobrestados ou em arquivo provisório, aguardando alguma situação jurídica futura. Durante o ano de 2016 ingressaram 29,4 milhões de processos e foram baixados 29,4 milhões. Um crescimento em relação ao ano anterior na ordem de 5,6\% e 2,7\%, respectivamente. Mesmo tendo baixado praticamente o mesmo quantitativo ingressado, com Índice de Atendimento à Demanda na ordem de $100,3 \%$, o estoque de processos cresceu em 2,7 milhões, ou seja, 3,6\%, chegando no final de 2016 a 79,7 milhões aguardando alguma solução definitiva. Fonte: http://www.tst.jus.br/documents/18640430/06db633a-a9bd-3e4f-d e15-5299c54c7219. Ver também Fonte, Relatório "Justiça em Números 2017", CNJ, disponível em : http://www.cnj.jus.br/files/conteudo/arquivo/2017/12/b60a659e5d5cb79337945cldd137496c.pdf 
dos temas encaminhados à Justiça do Trabalho referem-se às parcelas decorrentes das despedidas, "Rescisão do Contrato de Trabalho", seguido da "Remuneração e Verbas Indenizatórias" em 19,3\%. A soma dessas principais demandas chega a $80,0 \%$ do total, evidenciando, dessa forma, que a maioria absoluta das ações na Justiça do Trabalho está vinculada à instabilidade da permanência no emprego em um país onde não há reais garantias de emprego e ao não pagamento dos direitos básicos decorrentes do contrato de emprego, como salários e parcelas devidas nas despedidas, as chamadas parcelas rescisórias.

Grande parte das demandas decorre do descumprimento reiterado da tela de proteção por parte dos empregadores, em uma sociedade em que os limites ao despedimento são tênues e em que o sistema de multas por descumprimento necessita ser revisto para que se dê mais eficácia à ação preventiva da fiscalização. Ao invés disso, a reforma fragiliza a regulação pública, atingindo o próprio sistema de fiscalização e a Justiça do Trabalho, cuja finalidade primeira é a de concretizar um direito profundamente social e que nasceu na contramão do primado da "autonomia das vontades".

Tabela 1 - Principais Temas Encaminhados Para Justiça do Trabalho em 2016

\begin{tabular}{c|c|c}
\hline Tema discutido & $\mathbf{N}^{\mathbf{0}}$ de processos com o tema & $\mathbf{\%}$ \\
\hline Rescisão do Contrato de Trabalho & 18.341 .347 & 60,75 \\
Remuneração e Verbas Indenizatórias & 5.824 .952 & 19,29 \\
Responsabilidade Civil do Empregador & 2.583 .404 & 8,56 \\
Férias & 1.538 .079 & 5,09 \\
Responsabilidade Solidária/Subsidiária & 765.489 & 2,54 \\
Categoria Profissional Especial & 280.786 & 0,93 \\
Outras Relações de Trabalho & 256.674 & 0,85 \\
Acordo e Convenções Coletivas & 247.340 & 0,82 \\
Direito sindical e Questões análogas & 211.832 & 0,7 \\
Prescrição & 66.664 & 0,22 \\
Sentença Normativa & 38.043 & 0,13 \\
Aposentadoria e Pensão & 28.750 & 0,1 \\
Direito de Greve/Lockout & 7.203 & 0,02 \\
\hline Total & 30.190 .563 & 100 \\
\hline
\end{tabular}

Fonte: www.cnj.jus.br

Relatório Justiça e Números, CNJ. 
$\mathrm{Na}$ Argentina, houve reformas liberalizantes introduzidas nos anos 1990, cujos impactos negativos são destacados no aumento da pobreza, da indigência e do desemprego. ${ }^{18} \mathrm{Em} 2015$, o Congresso aprovou lei visando a colocar freios às despedidas, onerando-as, porém foi vetada pelo Presidente Macri que, em 2017, apresentou ampla reforma trabalhista, referindo-se à brasileira como paradigma e que, contando com expressiva resistência sindical e da sociedade intensificada, sobretudo, em dezembro de 2017, teve sua tramitação suspensa. Ainda que, por força da expressiva mobilização das organizações sindicais e de setores da sociedade, a tramitação dessa proposta tenha sido suspensa pelo governo, é importante que se analisem seus aspectos, até porque, recentemente, o governo optou por retomar o tema da reforma por meio de três projetos separados, encaminhados ao Parlamento, que se inserem como parte das medidas de ajuste em andamento, como a ainda neste item se abordará.

Quando ao projeto original, cuja tramitação foi suspensa, a reforma argentina também veio acompanhada por intenso debate em torno da excessiva judicialização dos conflitos, como no Brasil. Nos estudos desenvolvidos no âmbito do CESIT, que fundamentam este artigo, se procurou ver as estatísticas sobre a judicialização na Argentina. Porém, distintamente do que ocorre no Brasil, as nacionais argentinas sobre litigiosidade são limitadas às ações que discutem acidentes de trabalho e doenças ocupacionais. Sendo o modelo judicial descentralizado, não há estatísticas nacionais do sistema de litígios do trabalho. Algumas províncias produzem seus dados, porém com métodos distintos e inviáveis de serem avaliados com rigor. Grande parte das estatísticas é elaborada por Seguradoras de Riscos do trabalho, do setor privado, dificultando as comparações com os dados brasileiros do CNJ e do TST. ${ }^{19}$

Quanto às suas linhas estruturantes, as reformas brasileira e argentina apresentam aspectos precarizantes, tais como: exclusão da parte variável da natureza salarial; rebaixamento das condições

18 Salvia et al. (2000).

19 Ver a respeito (Krein, Gimenez, Santos, 2018, pp. 209-242). Mas mesmo com tal limite, os dados obtidos mostram entre 2010 e 2015 que do número de ações ajuizadas por tipo de adoecimento envolvendo acidentes de trabalho, doença profissional, acidentes no trajeto do trabalho (in itinere) e fora do local de trabalho, as ações por acidente e por doenças profissionais, que legalmente se equiparam aos acidentes, foram as que mais cresceram. 
de trabalho mediante acordo individual; alteração das condições de trabalho unilateralmente pelo empregador; retirada dos freios à terceirização, eliminando a responsabilidade solidária que a legislação argentina contempla; contratos de trabalho "autônomo" economicamente vinculado e trabalho "autônomo" independente com colaboradores; redução das indenizações por despedida (novidade da proposta argentina em relação à brasileira: constituição de fundo para pagamento das verbas rescisórias); contratos em tempo parcial; mitigação dos riscos (anistia) pelo contrato sem registro ou registrados de forma inadequada. O projeto reduz o prazo de prescrição de 2 anos para 1 ano (no caso da brasileira, a lei traz a prescrição intercorrente, até aqui adotada por minoritária jurisprudência). Distintamente da brasileira, a argentina traz alguns benefícios como ampliação ao pai da licença pelo nascimento de filho (de 2 para 15 dias), redução da jornada por acordo para cuidar de menore ${ }^{20}$, licença para adoção e tratamentos de reprodução assistida, além de políticas de capacitação e formação profissional.

Como referido anteriormente, a proposta de reforma fortemente resistida pela sociedade argentina e, em especial, pelas organizações sindicais em massivas manifestações, teve sua tramitação suspensa enquanto no Parlamento. No entanto, visando a facilitar sua aprovação, o governo desmembrou as propostas, apresentando três projetos em tramitação e sobre os seguintes aspectos: (i) regularização do emprego sem registro (informal) já denunciado quando de sua apresentação em 2017 pelo seu caráter regressivo e flexibilizador ao permitir que o trabalhador renuncie direitos adquiridos. $\mathrm{Na}$ Argentina, o trabalho sem registro responde por aproximadamente $33,7 \%$. Como estimulo à formalização é oferecida aos empregadores anistia pelas dívidas de contribuições previdenciárias, multas, infrações e extinção de ações penais; (ii) o segundo projeto propõe alterações na lei do contrato de trabalho com redução das indenizações por despedida, renúncia a direitos adquiridos e acordos individuais que modificam condições de trabalho; o projeto permite a "livre' negociação entre as partes podendo suprimir ou modificar de

$20 \mathrm{O}$ que pode ser uma armadilha para as mulheres que, na ausência de políticas públicas, são incentivadas a ficar em casa nas tarefas de cuidados. 
forma regressiva direitos via o acordado entre as partes, violando o princípio da irrenunciabilidade dos direitos decorrentes de normas de ordem pública; e, (iii) o terceiro projeto trata da capacitação laboral contínua, sistema de práticas formativas, emprego juvenil, rede federal de serviços de emprego e seguro desemprego ampliado, prevendo a criação de um documento de identidade ocupacional "Perfil Digital de Identidad Ocupacional". Trata-se de ferramenta vista com grande preocupação pelos trabalhadores na medida em que a realidade do mercado de trabalho é marcada por práticas discriminatórias e o acesso a dados de privacidade para avaliar se as pessoas estão adequadas ao posto de trabalho sugere uma seleção prévia dos indivíduos que se enquadram em determinados estereótipos com consequências danosas, especialmente para as mulheres e imigrantes. (Asociación de Abogados y Abogadas Laboristas, mayo, 2018).

Analisar a estratégia dos atores sociais diante desse cenário é de suma relevância quando se pensa a construção de uma sociedade menos desigual e mais justa.

\section{AS ESTRATÉGIAS DOS ATORES SOCIAIS NO BRASIL E NA ARGENTINA}

No Brasil, as instituições de regulação pública do trabalho - Justiça do Trabalho, Ministério Público do Trabalho e Centrais Sindicais - enfrentam fortes ataques com intuito de fragilizá-las e impor novos padrões de relações do trabalho com a prevalência do negociado sobre o legislado. Na Argentina, expressiva aliança entre as Centrais Sindicais, as instituições do direito do trabalho e o movimento social conseguiu frear o avanço no legislativo da proposta originalmente encaminhada pelo governo, o que reforça a tese de que o direito é uma relação, estando nas lutas que se dão da sociedade sua fonte material. O Governo Macri, porém, visando a aprovar as reformas precarizantes, fatiou-a em distintos projetos como forma de facilitar a aprovação e neutralizar a resistência organizada à proposta original. Com essa estratégia, em abril de 2018 encaminhou ao Parlamento os três projetos de lei antes referidos. 
No Brasil, entre as estratégias para revogar a lei 13.467/17 temos as iniciativas, já em 2017, de parte das Centrais Sindicais de: propor plebiscito revogatório, autorizado pela Constituição de 1988; formar comissão no âmbito das instituições públicas do trabalho, conduzida pela Comissão de Direitos Humanos do Senado Federal, com o objetivo de construir novo estatuto do trabalho como antídoto à Lei 13.467/17 (a versão preliminar do Estatuto foi lançada oficialmente no Senado Federal em 10 de maio de 2018); integrar os Fóruns que defendem a tela pública de proteção ao trabalho e se coloquem contra o esvaziamento dos direitos fundamentais assegurados na Constituição de 1988. Um deles, o Fórum Interinstitucional em Defesa do Direito do Trabalho e da Previdência Social, FIDS, integrado por entidades do mundo jurídico, de representação da magistratura, do sistema de fiscalização e do meio sindical, como é o caso do Fórum Nacional em Defesa dos Direitos dos Trabalhadores Ameaçados pela Terceirização, Fórum, tendo como secretária executiva a Associação Nacional dos Procuradores do Trabalho, ANPT. Essas entidades e o Fórum, que se notabilizaram na luta contra a terceirização, se têm expressado publicamente contra a reforma trabalhista por meio de notas técnicas, resoluções ou por decisões de suas respectivas instâncias de atuação, como se depreende da nota da Associação Nacional dos Magistrados do Trabalho, Anamatra, uma das integrantes do Fórum:

\section{$[\ldots]$}

Lei $\mathrm{n}^{\mathrm{o}} 13.467 / 2017$, relativa à reforma trabalhista, não pode ser aplicada aos processos ajuizados antes de 11 de novembro de 2017. A reforma deve ser aplicada de acordo com a Constituição Federal e as convenções e tratados internacionais e os juízes do Trabalho, em suas decisões, não podem ser tolhidos na sua livre convicção motivada. Essas e outras diversas questões foram decididas na Plenária que encerrou, neste sábado (5/5), o $19^{\circ}$ Congresso Nacional dos Magistrados da Justiça do Trabalho. (Anamatra, 5 de maio de 2018).

A reação contrária à reforma trabalhista foi imediata. No dia seguinte à apresentação à Câmara dos Deputados, 24 de dezembro 
de 2016, um conjunto de entidades lançou a nota "Quando o saco de maldades vira presente de natal, cujos Extratos abaixo demonstram uma forte oposição às medidas então em discussão:

\section{[...]}

A reforma trabalhista inconstitucional proposta pelo governo Temer insere-se em um amplo pacote de maldades que atropela os direitos sociais, incluídos os do trabalho, evidenciando um modelo de Estado e de sociedade que já se comprovou nefasto em outros países, com políticas de austeridade propaladas como sendo a via única para recuperar a economia e equilibrar as contas públicas cujos resultados, porém, têm sido catastróficos em outros experimentos internacionais, não resultando em crescimento e em equilíbrio fiscal ${ }^{21}$. Nesse pacote, além da já aprovada PEC 55 (que congela o gasto público por vinte anos mas, por outro lado, permite a transferência de valores e riqueza aos rentistas do Tesouro), estão a Reforma da Previdência, penalizando os mais necessitados, e a Reforma Trabalhista que se expressa em projetos de lei em andamento (PLC 30/2015 que amplia a terceirização para quaisquer atividades, PEC 300/2016, entre outros) e nas recentes medidas anunciadas como "presente de natal" que, fundadas na tese da prevalência do negociado sobre o legislado, rompem com o princípio da hierarquia dinâmica das fontes (que autoriza seja aplicada a norma mais benéfica ao trabalhador), aliás, uma das expressões do princípio da proteção, razão de ser do Direito do Trabalho. (Publicada em 24 de dezembro de 2016). ${ }^{22}$

Esses movimentos evidenciam que as reformas, embora contando com amplo apoio no legislativo, sendo aprovadas, não encontram respaldo na sociedade e, tampouco, junto à maioria dos Ministros do Tribunal Superior do Trabalho, TST, que se posicionou, no Senado Federal, contrariamente à reforma. As entidades sindicais, por seu turno, têm buscado colocar travas à reforma via introdução

21 Ver http://brasildebate.com.br/wp-content/uploads/Austeridade-e-Retrocesso.pdf 22 Trata-se de nota publicada por entidades que compõem o Fórum Nacional em Defesa dos Direitos dos Trabalhadores Ameaçados pela Terceirização, Fórum, que congrega todas as Centrais Sindicais, representantes de entidades de magistrados, procuradores, advogados, acadêmicos, pesquisadores, estudantes, movimentos sociais e sindicalistas e que hoje integra a coordenação do FIDS. 
de cláusulas nos instrumentos normativos (normas coletivas) que assegurem a preservação de direitos. As iniciativas no âmbito das instituições do Direito do Trabalho e das Centrais Sindicais sinalizam para longo processo de resistência e de luta contra a retirada de direitos e a precarização (Biavaschi; Teixeira, 2018, mimeo).

Ainda que com contradições e dificuldades, as Centrais mobilizaram-se para enfrentar a reforma. $\mathrm{O}$ ápice desse processo se deu com a organização de greve geral em 28 de abril de 2017 contra as reformas trabalhista e previdenciária. No dia 27 de abril, a Câmara aprovou o projeto da reforma trabalhista que seguiu para o Senado. O debate no Senado foi marcado por controvérsias, ações organizadas, memoriais, textos, audiências públicas. De um lado, era forte pressão dos setores econômicos e financeiros no sentido da aprovação da proposta tal como veio da Câmara dos Deputados, para que não retornasse à Câmara caso houvesse alguma modificação. De outro, parte expressiva de representantes do mundo do trabalho e de algumas Centrais, compreendendo a insustentabilidade da proposta em seus pressupostos, defendia a rejeição integral do projeto. Enquanto isso, parte das Centrais negociava a retirada de alguns aspectos que consideravam mais nefastos aos interesses dos trabalhadores e das entidades sindicais, como é o caso do fim do imposto sindical e a permissão para as mulheres gestantes ou em amamentação trabalharem em local insalubre.

A rapidez na tramitação, a força dos interesses econômicos e da mídia, a não compreensão, desde logo, pelos destinatários da proposta de sua real perversidade e a divisão de estratégias entre as Centrais talvez tenham sido elementos que dificultaram apoio maior da sociedade no sentido da rejeição da proposta, diferentemente do que se deu com a reforma da previdência. Mesmo assim, as opiniões contrárias ao projeto incomodaram os "donos do poder", tanto que a reação do aparelho repressivo do Estado contra os manifestantes foi violenta. Apesar de tudo isso e conquanto, em número expressivo e majoritário, Ministros do TST tenham ido ao Senado para, via documento escrito, manifestar o caráter regressivo da proposta e, ainda, mesmo que o próprio relator tenha destacado pontos negativos que seriam objeto de veto do Presidente da República, o projeto foi apro- 
vado na integra no dia 11 de julho sem que o prometido veto se tenha concretizado, conforme fora alardeado pelo relator e por Senadores da base do governo. Na realidade, o Senado, abriu mão de seu poder revisional e, mesmo reconhecendo haver pontos com os quais os Senadores a base não concordavam, devendo ser vetados, aprovou o projeto sem alterações, com os votos contrários da oposição.

Os vetos não vieram. Entre a aprovação e a entrada em vigência da reforma, designada para novembro de 2017, circularam várias propostas de Medida Provisória com o intuito que corrigir aspectos considerados polêmicos, em especial quanto à fonte de custeio dos sindicatos, sem êxito. A Medida Provisória n. 808/17, encaminhada ao Congresso em novembro de 2017, perdeu validade em 24 de abril de 2018 sem ter sido apreciada pela Câmara Federal. Enquanto esteve vigente recebeu mais de 900 emendas.

Nesse ínterim, ainda que de forma tímida, vários aspectos da reforma foram sendo implementados. A possibilidade de se recolocar a lei em discussão oportunizada pela MP 808/17 não estava totalmente descartada. Mas foi nos ataques ao custeio sindical e na restrição à participação dos sindicatos na assistência às despedidas, a chamadas "homologações" sindicais, que se concentraram as primeiras medidas.

Em vigor a reforma, as inseguranças ampliaram-se, com impacto negativo na desigualdade ${ }^{23}$. Contribuíram para essa ampliação a inclusão dos contratos intermitentes e dos avulsos de forma continuada (em total desrespeito aos princípios que fundamentam o direito do trabalho). As contratações na modalidade de contratos intermitentes iniciaram-se e, desde novembro de 2017, se vêm intensificando a cada mês com saldo em maio de 2018 de 20.213 postos de trabalho. Não há dados sobre o número de horas trabalhadas, o que significa que muitos mascaram condição de subutilização da força de trabalho por trabalhar menos de 40 horas e manifestar vontade de trabalhar mais. Por outro lado, as ocupações com predominância desse tipo de contrato são os vigilantes, atendentes de lojas e mercados, embaladores, mecânico de manutenção, recepcionista, assistente de vendas, repositor de 23 Ver matéria publicada no Brasil Debate e no Jornal Valor Econômico "Reforma Trabalhista aumentou a desigualdade", veiculando o trabalho de Bárbara Vallejos Vazquez, Euzebio Jorge Silveira de Sousa e Ana Luíza Matos de Oliveira , disponível em: https://www.valor.com.br/brasil/5617411/reforma-trabalhista-aumentou-desigualdade-dizem-pesquisadores. 
mercadorias, serventes e vendedores do comércio varejista, ocupações que se caracterizam pela presença de baixa remuneração. Em maio de 2018 os desligamentos por "acordo mútuo" já somavam 67.474. Já o desemprego continua alarmante. E a judicialização que, inicialmente, segundo dados do TST, sofreu forte redução, voltou a crescer sem que, ainda, se possa concluir por uma curva de tendência dada à proximidade da vigência da lei da reforma ${ }^{24}$.

No campo da negociação coletiva, conforme dados do Mediador/Ministério do Trabalho, sistematizados para o período entre janeiro e abril de 2018 pelo Dieese (2018), destaca-se a presença de 112 instrumentos coletivos envolvendo a negociação de 223 tipos de cláusulas específicas sobre os temas da reforma trabalhista. Ainda que sejam dados preliminares, uma vez que refletem a realidade das categorias em campanha salarial neste primeiro semestre, permitem consolidar um primeiro balanço das principais medidas que estão sendo implementadas pelas empresas. Destacam-se entre elas as que se dirigem às condições de trabalho, tais como: jornada, intervalo intrajornada, parcelamento de férias, banco de horas, ultratividade, homologação, contrato de trabalho, contribuição assistencial, salários e remuneração com prevalência de cláusulas que tratam das novas modalidades de contratação, especialmente no setor de serviços e cláusulas sobre jornada de trabalho com predominância no setor industrial. Do total das 223 cláusulas, $48 \%$ apenas reitera o que já está previsto na Lei 13.467/17.

Em junho de 2018, as Centrais Sindicais ${ }^{25}$ organizaram ato político e lançaram a Agenda Prioritária da Classe Trabalhadora. O documento contém 22 pontos e o que chama atenção é o tratamento em relação à reforma trabalhista. Da leitura desse documento vê-se não haver entendimento unânime de que a legislação como um todo seja revogada, havendo referência à retirada de todos os aspectos negativos que precarizam as condições de trabalho, como segue ${ }^{26}$ :

24 Ver, a respeito: https://www.cartacapital.com.br/politica/Apos-reforma-numero-de-novos-processos-trabalhistas-caiu-pela-metade.

25 Participaram da elaboração CUT, Força Sindical, CTB, UGT, NSCT, Intersindical e CSB.

26 A integra do documento está disponível em: https://www.diap.org.br/images/stories/agenda prioritaria_classe_trabalhadora_2018.pdf. 
$[\ldots]$

Revogar todos os aspectos negativos apontados pelos trabalhadores da Lei 13.467 (Reforma Trabalhista) e da Lei 13.429 (Terceirização), que precarizam os contratos e condições de trabalho, na perspectiva da construção de um novo estatuto, com valorização do trabalho" (Item 6 da plataforma).

A ausência de entendimento único sobre a melhor estratégia para enfrentar a reforma trabalhista e o fato de algumas Centrais assinalarem a existência de aspectos positivos revelam os imensos desafios a serem enfrentados nesse próximo período. Por outro lado, o fim do imposto sindical coloca em dúvida a própria existência de parte dos sindicatos no Brasil por não terem condições de sobreviver sem essa fonte de custeio.

Como enfrentar os avanços das medidas de precarização das relações de trabalho diante de um quadro de profunda fragilidade e desintegração? A experiência Argentina vem demonstrando uma grande sintonia entre o combate a reformas laborais sintetizados nos três projetos enviados ao Senado e a luta mais geral contra as políticas de austeridade econômica e o projeto ultraliberal de Macri, na medida em que as jornadas de luta contra as medidas econômicas ganham as ruas e se fortalece o combate às reformas laborais no país.

\section{CONSIDERAÇÕES FINAIS}

A reforma trabalhista serve a claros propósitos: ampliar o poder de os empregadores definirem as regras que regem os contratos de trabalho; aumentar a insegurança dos trabalhadores, colocando-os em situação de submissão ao comando do capitão; reduzir os trabalhadores a um contingente de baixa remuneração, disponíveis ao capital com jornadas flexíveis, remuneração instável e com direitos suprimidos; limitar o poder de atuação da Justiça do Trabalho, reduzindo sua capacidade de colocar freios ao "livre trânsito" de um capitalismo sem peias; pulverizar a ação sindical com multiplicidade de instrumentos normativos que, no limite, poderão ser ajustados por empresa. Em cenário de profunda crise, a avalanche neoliberal que chegara na Améri- 
ca Latina na década de 1990 e que vinha sendo resistida em muitos de seus aspectos, voltou a produzir efeitos com força a partir do impeachment da Presidenta Dilma Rousseff e da posse do Macri na Argentina. Reformas estruturais propostas pelos setores econômicos e financeiros foram encaminhas ao Parlamento, tanto na experiência brasileira, quanto argentina sob os mesmos argumentos: melhorar a competitividade com os setores externos, gerar empregos, promover a retomada da atividade econômica e recuperar os investimentos produtivos. Daí se compreender a reforma trabalhista de forma sistêmica, englobando tanto o texto específico da Lei $\mathrm{n}^{\circ}$ 13.467/2017 no Brasil e os projetos de Lei na Argentina, quanto um conjunto de políticas estruturais e projetos de lei que tendem a impactar negativamente os "instrumentos que sustentam o Estado indutor do crescimento econômico e promotor das políticas sociais" (Rossi, Mello, 2017). Essa compreensão está presente nos estudos desenvolvidos na pesquisa realizada no âmbito do CESIT, que fundamentam este texto.

Por outro lado, as experiências do Brasil e da Argentina demonstram que há resistência e capacidade de luta dos setores organizados da sociedade. As pressões sociais evidenciam a continuidade de um cenário de muita disputa e tensão para barrar esse desmonte. Em meio à ação persistente de forças sociais, afloram novas experiências de organização, por meio dos movimentos populares, de mulheres, de juventude, de moradia e sindical protagonizando formas de enfrentamento e luta frente às medidas de retrocesso social, juntamente com setores e instituições progressistas da sociedade.

\section{REFERÊNCIAS}

ADASCALITEI, D.; MORANO, C. P. Drivers and effects of labour market reforms: Evidence from a novel policy compendium. IZA, Journal of Labor Policy, Vol.5, n. 15. Disponível em: https:/izajolp. springeropen.com/articles/10.1186/s40173-016-0071-z Acesso em: mar. 2018.

ANAMATRA. Reforma trabalhista deve ser aplicada de acordo com a Constituição Federal. Disponível em: https://www.anamatra.org. br/imprensa/noticias/26463-plenaria-conamat. Acesso em: mar. 2018. 
ATKINSON, A. B. Desigualdade. O que pode ser feito? São Paulo: LeYa, 2015.

Asociación de abogados y abogadas laboristas. Reforma laboral. Documento crítico sobre los projectos de ley presentados por el Poder Ejecutivo Nacional. Laboristas.net. mayo/2018.

BAUMAN, Z. Vida para o consumo. A transformação das pessoas em mercadoria. Rio de Janeiro: Zahar, 2008.

BELlUZZO, L. G. O Capital e suas metamorfoses. São Paulo: Unesp, 2013.

BELLUZZO, L. G.; GALIPOLO, G. Manda quem pode, obedece quem tem prejuizo. São Paulo. Editora Contracorrente, 2017.

BIAVASCHI, M. B; TEIXEIRA, M. O. A regulamentação da terceirização em perspectiva comparada: Brasil, Argentina e Uruguai. In: LEITE, M. de P. (Org). Contradições do Trabalho. 2018, mimeo.

BIAVASCHI, M. B. As reformas estruturantes em um país em que jagunços ainda têm vez: A Reforma Trabalhista que não cria empregos e suprime direitos. In: TEIXEIRA, M. O. et al. (Orgs.). Contribuição critica à Reforma Trabalhista. Campinas, SP: UNICAMP/CESIT, 2017.

BIAVASCHI, M. B.; SANTOS, A. L. dos; DROPPA, A. A dinâmica da regulamentação da terceirização no Brasil: as súmulas do Tribunal Superior do Trabalho, os projetos de lei e as decisões do Supremo Tribunal Federal. Revista Política e Trabalho, no. 41, pp.121-145, 2014.

CARTA CAPITAL. Após reforma, número de novos processos trabalhistas caiu pela metade. Disponível em: https://www.cartacapital.com.br/ politica/Apos-reforma-numero-de-novos-processos-trabalhistascaiu-pela-metade. Acesso em: out.2018.

CNJ. Conselho Nacional de Justiça. Disponível em: www.cnj.jus.br. Acesso em: out.2018.

CTA Argentina. Conferencia. Disponível em: http://www.cta.org.ar/IMG/ mp3/conferencia_prensa_cta_25_junio.mp3. Acesso em: out.2018.

DIAP. Agenda Prioritária da Classe Trabalhadora. Disponível em: https:/ www.diap.org.br/images/stories/agenda_prioritaria_classe trabalhadora_2018.pdf. Acesso em: out. 2018.

DIEESE. Impacto da reforma trabalhista nas cláusulas sociais negociadas. Subseção do Dieese do Sindicato dos Químicos de São Paulo, São Paulo, 2018.

FEDERAÇÃO DOS TRABALHADORES NO COMÉRCIO NO ESTADO DE SANTA CATARINA. Quem somos. Disponível em: http:// Www.fecesc.org.br/quem-somos/ Acesso em: Out. 2018.

G1. Lucro das empresas de capital aberto cresce 9,4\% em 2016. Disponível 
em: https:/g1.globo.com/economia/negocios/noticia/lucro-dasempresas-de-capital-aberto-cresce-94-em-2016.ghtml. Acesso em: mar. 2018.

GRAU, E. Ensaio e discurso sobre a interpretação/aplicação do direito. São Paulo: Malheiros, 2002.

HABERMAS, J. Diagnósticos do tempo. Seis ensaios. Rio de Janeiro: Tempo brasileiro, 2005.

ILO. WORLD EMPLOYMENT SOCIAL OUTLOOK. Disponível em: https://bit.ly/2PIDj6n . Acesso em: Out. 2018.

ILO. The Future of Work We Want: A Global Dialogue. Disponível em: https:/www.ilo.org/global/topics/future-of-work/dialogue/lang-en/index.htm. Acesso em: Out. 2018.

KREIN, J. D.; GIMENEZ, D. M.; SANTOS, A. L. dos. Dimensões criticas da reforma trabalhista no Brasil. Campinas: Curt Nimuendajú, 2018.

LIPIETZ, A. La flexibilidad laboral. Revista Doxa, 1541, entrevista realizada por Ana Dinerstein y Silvio Santantonio. 29-31, 1994.

OECD. The Labour Share in G20 Economies. Disponível em: https:/www. oecd.org/g20/topics/employment-and-social-policy/The-LabourShare-in-G20-Economies.pdf. Acesso em: mar. 2018.

PIKETTY, T. Capital in the Twenty-First Century. Cambridge: Harvard Uni-versity Press, 2014.

POULANTZAS, N. Estado, o poder, o socialismo. Rio de Janeiro: Graal, 1990.

ROSSI, P.; MELLO, G. Choque recessivo e a maior crise da história: A economia brasileira em marcha à ré. Centro de Estudos de Conjuntura e Política Econômica - IE/UNICAMP. Nota do Cecon, $\mathrm{n}^{\mathrm{o}}$. 1, Abril de 2017 https://www3.eco.unicamp.br/images/arquivos/ NotaCecon1_Choque_recessivo_2.pdf

RUBERY, J. Structured Labour Markets, Worker Organisation and Low Pay. Cambridge Journal of Economics, Vol. 2, nº. 1, pp.17-36, 1978.

SALAS, C. Labour, income and social programmes in contemporary Mexico. In: United Nations Development Programme, Social Protection, Growth and Employment: Evidence from India, Kenya, Malawi, Mexico, Peru and Tajikistan. UNDP, New York, pp. 201230, 2013.

SALVIA, A.; TISSERA, S.; BUSTOS, J. M.; SCIARROTTA, F.; PERSIA, J.; GALLO, G. H.; CILlYS, N. y ALLEGRONE, V. G. Reformas laborales y precarización del trabajo asalariado (Argentina 19902000). Equipo Cambio Estructural y Desigualdad Social. Cuadernos del CEPED, Buenos Aires, Argentina, nº. 4, 2000. Disponível em: https://www.aacademica.org/agustin.salvia/218.pdf 
STREECK, W. Tempo Comprado. A crise adiada do capitalismo democrático. Coimbra: Actual Editora, 2013.

SUNDARARAJAN, A. The Sharing Economy: The End of Employment and the Rise of Crowd-Based Capitalism. Cambridge: MIT, 2016

TEIXEIRA, M. O. et. al. Contribuição crítica à reforma trabalhista. UNICAMP/IE/CESIT, Campinas, 2017.

TOMADA, C. et al. Argentina en Reforma: revisando la demolición de derechos. Buenos Aires, Mimeo, 2017.

VALOR ECONÔMICO. Reforma trabalhista aumentou a desigualdade. Disponível em: https:/www.valor.com.br/brasil/5617411/reformatrabalhista-aumentou-desigualdade-dizem-pesquisadores. Acesso em: jul. 2018.

VASQUEZ. B. V; SOUSA, E. J. S. de; OLIVEIRA, A. L. M de. Reforma trabalhista aumentou a desigualdade. Disponível em: https:// www.valor.com.br/brasil/5617411/reforma-trabalhista-aumentoudesigualdade-dizem-pesquisadores. Acesso em: jul. 2018.

\section{Sites:}

TST: www.tst.jus.br 